\title{
IMPLEMENTASI UU NOMOR 38 TAHUN 1999 PASAL 16 TENTANG PENDAYAGUNAAN ZAKAT DI BAZ KABUPATEN MALANG
}

\author{
Abd. Rozaq \\ Fakultas Syariah UIN Maliki Malang \\ Telepon: 081333993833 \\ Email:Abd.rozaq@gmail.com
}

\begin{abstract}
Efficiency of Zakat becomes the most vital source of funds that can be utilized for the welfare of the community, especially to alleviate people from poverty and eliminate social inequality, and therefore this sector is used as a measure of success of a Baz / LAZ in Malang. This study used a qualitative descriptive method with sociological or empirical approach, in data collection using interviews and documentation so that primary data is the result of interviews and the data available at the Office Baz Malang. While in data analysis using descriptive manner. The results of this study indicate that the utilization of funds Baz ZIS in Malang Regency is in conformity with article 16 of Law No.38 of article 1, but in article 2 of this Baz Malang Regency is not maximized due to lack of cooperation among managers with mustahiq.

Pendayagunaan zakat menjadi sumber dana yang paling vital sehingga dapat dimanfaatkan bagi kesejahteraan masyarakat terutama untuk mengentaskan masyarakat dari kemiskinan dan menghilangkan kesenjangan sosial, oleh karena itu sektor ini dijadikan sebagai tolak ukur tingkat keberhasilan sebuah BAZ/LAZ di Kabupaten Malang. Penelitian ini menggunakan metode deskriptif kualitatif dengan pendekatan sosiologis atau empiris, dalam pengumpulan data menggunakan metode wawancara dan dokumentasi sehingga data primernya adalah hasil wawancara dan data yang ada di Kantor BAZ Kabupaten Malang. Sedangkan dalam analisa data menggunakan cara deskriptif. Hasil penelitian ini menunjukkan bahwa pendayagunaan dana ZIS di BAZ Kabupaten Malang sudah sesuai dengan UU No.38 pasal 16 pasal 1, akan tetapi pada pasal 2 ini BAZ Kabupaten Malang belum maksimal disebabkan kurang adanya kerja sama antar pengelola dengan mustahiq.
\end{abstract}

Kata Kunci: Pendayagunaan, Prioritas, pelaksanaan.

Zakat adalah pilar Islam setelah syahadat dan salat. Setelah orang masuk Islam dengan ditandai pernyataan dua syahadat, orang itu harus melaksanakan Salat dan mengeluarkan zakat di samping berpuasa Ramadlan dan berhaji jika mampu. Tali perhubungan dengan Allah diikat dengan Shalat, sedangkan tali perhubungan sesama manusia diikat dengan zakat. Dua ikatan itulah berkali-kali disebut oleh Allah di dalam al-Qur'an secara bersama-sama pada 28 tempat. ${ }^{1}$

Zakat adalah suatu ibadah amaliyah yang lebih menjurus kepada aspek sosial, untuk mengatur kehidupan manusia dalam hubunganya dengan Allah, dan dalam hubunganya dengan sesama manusia. Kalau salat lebih menjurus kepada pembinaan kepribadian yang mulia, maka zakat lebih menjurus kepada pembinaan kesejahteraan masyarakat. ${ }^{2}$ Oleh sebab itu tidak diheran jika ibadah zakat ini juga merupakan

\footnotetext{
1 Sjechul Hadi Permono, "UU Nomor 38 Tahun 1999 dan pemberdayaan pengelolaan Zakat," makalah, disajikan pada Rapat Kerja Badan Amil Zakat Kabupaten Malang, tanggal 27 Agustus(Malang: Aula Pemerintah Kabupaten Malang, 2001), h. 1.

2 Muhammadiyah Ja'far, Zakat, Puasa dan Haji (Malang: Kalam Mulia, 1985), h. 3 .
}

ibadah bagi umat-umat sebelum Islam, sebagaimana yang telah diterangkan Allah di dalam al-Qur'an. ${ }^{3}$

Sejarah Islam telah membuktikan bahwa dengan adanya Zakat yang dikelola secara optimal, ternyata negara menjadi sejahtera dan rakyat menjadi makmur. Di Singapura yang jumlah penduduk muslim kurang lebih 450.000 jiwa (kurang lebih $15 \%$ dari jumlah penduduk), pada tahun 1997 perolehan ZIS mencapai kurang lebih S\$ 14.300.000 (kurang lebih Rp 71.500.000.000,00). Di negara tersebut pelaksanaan ibadah zakat, infaq dan sadaqah telah diatur dalam Undang-Undang No. 27 tahun 1966 tentang administrasi orang-orang Islam, bagian IV pasal 57 sampai 73 tentang waqaf dan zakat. Di wilayah persekutuan Malaysia yang jumlah penduduk muslimnya kurang lebih 650.000 jiwa (kurang lebih 50\% dari jumlah penduduk), pada tahun 1997 perolehan ZIS mencapai kurang lebih RM 52.800.000 (kurang lebih Rp. 105.600.000.000,00). ${ }^{4}$

\footnotetext{
3 Surah al-Anbiya' ayat 73, Maryam ayat 54-55 dan ayat 30-31, dan al-Maidah ayat 12 Created with

4 Permono Nomor 38 Tahun 1999, $\mathbf{P D F}$
} 
Di Indonesia, sejak akhir tahun 1960 an, telah dirintis upaya-upaya pengelolaan zakat, melalui bermacam-macam usaha dan berbagai cara, akan tetapi baru tanggal 23 September 1999, dapat diwujudkan dalam bentuk Undang-Undang, yaitu UURI No. 38 tahun 1999 tentang pengelolaan zakat, sudah dikeluarkan Kepmenag No. 581 tahun 1999 tentang pelaksanaan Undang-Undang No. 38 tahun 1999 tentang pengelolaan zakat, dan sudah diterbitkan Pedoman teknis pengelolaan zakat dengan keputusan Direktur Jendral Bimbingan Masyarakat Islam dan urusan haji, nomor D/291 tahun 2001 dengan keputusan Presiden RI No. 8 Tahun 2001 tentang amil zakat nasional.

Pendayagunaan zakat merupakan bagian yang sangat penting, karena merupakan nilai jatuh bangunnya sebuah lembaga zakat, jika sebuah lembaga bisa mendayagunakannya dengan bagus otomatis pada sektor pengumpulan akan mengalami peningkatan karena masyarakat sudah tahu hasilnya, akan tetapi jika pada sektor pendayagunaan zakat ini tidak jalan maka otomatis masyarakat tidak akan percaya dan tidak memberikan zakatnya ke lembaga itu.

Menurut pengamatan sementara, bahwa daerah Kabupaten Malang memiliki potensi zakat yang tidak kecil. Potensi besar seperti itu, tampaknya belum bisa ditangkap secara baik oleh lembaga-lembaga sosialkeagamaan khususnya yang bergerak dalam bidang pengelolaan zakat di mana selama ini pengelolaan zakat masih banyak dilakukan secara tradisional baik dalam pengumpulan maupun pendistribusian.

Menurit Sadewo ${ }^{5}$ bahwa pada sektor pendayagunaan ini merupakan nilai jatuh bangunnya bagi sebuah lembaga zakat karena pada sektor ini memerlukan sebuah kreatifitas yang lebih untuk mengembangkan dana ZIZ, sebagaimana yang telah dikemukakan oleh Eri Sudewo bahwa sesungguhnya jatuh bangunnya sebuah lembaga zakat terletak pada kreatifitas divisi pendayagunaan. Boleh-boleh saja lembaga zakat memiliki struktur organisasi yang lengkap serta ditunjang oleh fasilitas yang lengkap dan juga boleh didukung oleh nama-nama besar, karena dari situ masyarakat dapat mengetahui sejauh mana performa lembaga zakat.

Sebagaimana di dalam UU No. 38 tahun 1999 BAB V pasal 16 disebutkan pada poin (1) " $\mathrm{Ha}$ sil pengumpulan zakat didayagunakan untuk mustahiq sesuai dengan ketentuan agama. Poin (2) Pendayagunaan hasil pengumpulan zakat berdasarkan skala prioritas kebutuhan mustahiq dan da-

5 Eri Sudewo, Manajemen Zakat (Ciputat: Institut Manajemen Zakat, 2004), h. 218. pat dimanfaatkan untuk usaha yang produktif. Dari ketentuan pasal tersebut pendayagunaan juga merupakan nilai bagi pengelola untuk mengetahui kinerja BAZ sehingga sesuai dengan yang diharapkan oleh UU No. 38 Tahun 1999.

Berdasarkan hasil pengamatan sementara, kinerja dari pihak pengelola BAZ yang ada di Malang terkesan kurang optimal sehingga belum memenuhi sasaran yang diharapkan. Hal ini diperkuat dari laporan BAZ bulan Agustus bahwa sisa sejumlah Rp 547.358.706 dari kas dan pemasukan bulan Agustus yang diperoleh dari dana ZIS sebanyak Rp 35.877.525 yang totalnya mencapai Rp 583.236.231 kemudian didayagunakan untuk tukar tambah hewan ternak di Kecamatan Jabung sebanyak Rp 100.000, bantuan keluarga tidak mampu di Desa Kendalpayak Kecamatan Pakisaji sebanyak Rp 150.000, bantuan guru tidak tetap Rp 28.800.000, beasiswa untuk siswa tidak mampu yang berprestasi Rp 4.250.000, bantuan untuk musafir Rp 25.000, bantuan sembako sebanyak 160 paket untuk Kecamatan Wonosari dan Kecamatan Wagir Rp 24.684.000 dan bantuan al-Qur'an, buku tajwid dan iqro' pada TPQ al-Amin Desa Sumberpang Kecamatan Wagir Rp 1.000.000, sehingga saldo Rp 524.227.231 dan terpakai kurang lebih 10\%.

Ada semacam kekhawatiran, trauma memberikan kepada mustahiq maupun keragu-raguan dari pengelola dalam mendayagunakan dana ZIS, yang sesuai dengan sasaran yang bersifat lebih luas, sesuai dengan citra dan rasa syara', dan diperkuat lagi dengan kurang optimalnya kinerja BAZ, mengingat beban yang sangat berat itulah peran BAZ di Kabupaten Malang terkesan kurang begitu optimal dalam mendayagunakan ZIS, sehingga muncul kekhawatiran dari kalangan masyarakat akan kinerja BAZ baik itu di sektor pengumpulan, pendisttibusian lebih-lebih di sektor pendayagunaan, sehingga muncul kekhawatiran kalau Zakat itu tidak akan sampai ke tangan penerima Zakat (mustahiq) yang sebenarnya berhak. ${ }^{6}$

Di Indonesia, pengelolaan zakat diatur berdasarkan Undang-Undang No. 38 Tahun 1999 dengan Keputusan Menteri Agama (KMA) No. 581 Tahun 1999 tentang pelaksanaan Undang-Undang tentang pengelolaan zakat. Pada Bab III UU No. 38 tahun 1999 dikemukakan bahwa organisasi pengelola zakat terdiri dua jenis, yaitu Badan Amil Zakat (pasal 6) dan Lembaga Amil Zakat (pasal 7). Selanjutnya pada bab tentang sangsi (Bab VIII) dikemukakan pula bahwa setiap pengelola zakat yang karena kelalaiannya ti- 
dak mencatat atau mencatat dengan tidak benar tentang zakat, infaq, shadaqah, sebagaimana yang dimaksud dalam pasal 8, pasal 12 dan pasal 11 UU No. 38 tahun 1999, diancam dengan hukuman kurungan selama-lamanya tiga bulan dan/atau denda sebanyakbanyaknya Rp 30.000.000,- (tiga puluh juta rupiah). Sanksi ini tentu dimaksudkan agar BAZ dan LAZ yang ada di negara kita menjadi pengelola dalam mendayagunakan zakat yang kuat, amanah dan profesional dan dipercayai masyarakat, sehingga pada akhirnya masyarakat senantiasa menyerahkan zakatnya kepada lembaga pengelola zakat.

Dana ZIS yang dimaksud pada pembahasan ini adalah dana zakat, infaq dan bentuk sadaqah serta amalan ibadah yang berbentuk harta kekayaan lainnya. Karena wilayah kerja BAZ Kabupaten Malang berkaitan dengan macam-macam sumber dana tersebut. Hal ini sesuai dengan aturan Undang-Undang yang berlaku, sebagaimana diatur dalam Keputusan Menteri Agama RI. Nomor 581 tahun 1999 tentang pelaksanaan Undang Undang Nomor 38 tahun 1999 tentang pengelolaan zakat, yaitu pasal 27 yang berbunyi, bahwa lingkup kewenangan pengumpulan zakat sebagaimana dimaksud pada pasal 25 termasuk harta selain zakat seperti infaq, hibah, wasiat, waris dan kafarat.

\section{METODE}

Jenis penelitian ini adalah deskriptif kualitatif, di qmana peneliti menggambarkan data hasil penelitian dengan kata-kata atau kalimat yang dipisah-pisah menurut kategori dan dianalisis untuk memperoleh kesimpulan. Sebelum dianalisis, data yang dihasilkan dari penelitian akan dideskripsikan terlebih dahulu, sekaligus mengkaji secara seksama tentang fenomena pendayagunaan Zakat yang terjadi di BAZ Kabupaten Malang.

Sedangkan pendekatan yang digunakan dalam penelitian ini adalah pendekatan sosiologis atau empiris. ${ }^{8}$ Jika ditinjau dari rancangan penelitian, maka penelitian ini digolongkan ke dalam penelitian deskriptif, adapun tujuan dari penelitian deskriptif ini adalah untuk menggambarkan suatu obyek secara sistematis, ${ }^{9}$ yaitu fenomena pendayagunaan zakat di BAZ Kabupaten Malang.

Bahwa untuk memperoleh data yang menunjang penelitian, maka akan digunakan teknik dalam pengumpulan data, yaitu: Pertama, wawancara, teknik

\footnotetext{
7 Suharsimi, Arikunto, Prosedur Penelitian; Suatu Pendekatan Praktek (Jakarta: Rineka Cipta, 1998), h. 243-244.

8 Soerjono Soekanto, Pengantar Penelitian Hukum (Jakarta: UI Press, 1986), h. 43.

9 Soekanto, Pengantar, h. 10.
}

wawancara dipergunakan peneliti untuk mendapatkan data tentang kegiatan percakapan antara pewawancara dan yang diwawancarai dengan maksud untuk mendapatkan informasi mengenai hal yang berkaitan dengan mekanisme pendayagunaan zakat di BAZ Kabupaten Malang, dalam hal ini penulis mewancarai Ketua dan Sekretaris BAZ Kabupaten Malang. Kedua, dokumentasi, teknik dokumentasi ini dilakukan untuk mendapatkan data-data yang berkaitan dengan pelaksanaan program lembaga, seperti pedoman pengelolaan, neraca dan laporan hasil pengumpulan dan pendayagunaan dana ZIS, daftar wajib zakat dan donatur, dan data-data yang berkaitan dengan sejarah perkembangan lembaga, serta data-data lainnya yang berkaitan dengan pokok penelitian.

Dokumen dan record digunakan untuk keperluan penelitian, menurut Guba dan Lincoln sebagaimana dalam Moleong, ${ }^{10}$ karena alasan-alasan yang dapat dipertanggungjawabkan, yaitu: (a) Dokumen dan record digunakan karena merupakan sumber yang stabil dan mendorong. (b) Berguna sebagai bukti untuk pengujian.

Sedangkan sifat dokumen yang diperlukan dalam penelitian ini adalah dokumen resmi internal, yaitu suatu dokumen yang dikeluarkan dan dimiliki oleh pihak Lembaga sebagai obyek penelitian yang telah mendapatkan legalitas atau pengesahan dari yang berwenang.

Untuk menghindari agar tidak terjadi banyak kesalahan dan untuk mempermudah pemahaman, maka peneliti dalam menyusun karya ilmiah ini melakukan beberapa upaya di antaranya adalah editing, yaitu memeriksa kembali data yang diperoleh terutama dari segi kelengkapan, keterbacaan tulisan, kejelasan makna, kesesuaian makna, keterkaitan satu dengan lainnya, relevansinya, keseragaman satuan dan maksud satuan-satuan rumus yang ada, guna untuk mengetahui apakah data tersebut sudah cukup baik dan bisa dipahami serta dapat segera dipersiapkan untuk keperluan proses berikutnya.

Langkah selanjutnya setelah data terkumpul kemudian peneliti melakukan classifying yakni mengklasifikasikan data-data yang telah diperoleh dari BAZ Kabupaten Malang agar lebih mudah dalam melakukan pembacaaan data sesuai dengan kebutuhan yang diperlukan, yaitu dengan jalan menyusun dan mensistematiskan data-data yang diperoleh dalam rangka paparan yang sudah direncanakan sebelumnya. Berikutnya melakukan verifying, yaitu memeriksa kembali data dan informasi dari BAZ 
Kabupaten Malang agar validitasnya bisa terjamin. Langkah berikutnya adalah analizing, menganalisa data yang penulis peroleh dari BAZ Kabupaten Malang agar lebih mudah dipahami, kemudian langkah terakhir yang dilakukan adalah concluding, yakni pengambilan kesimpulan dari data-data BAZ Kabupaten Malang yang penulis peroleh yang telah diolah terlebih dahulu, guna mendapatkan jawaban dari kegelisahan yang telah dipaparkan dalam latar belakang. ${ }^{11}$

Analisa data merupakan bagian yang sangat penting dalam metode ilmiah, karena dengan proses analisalah data tersebut dapat diberi arti dan makna yang berguna dalam memecahkan masalah penelitian. Menganalisis data merupakan tindakan peneliti untuk mempertemukan kesenjangan antara das sollen dan das sein, antara teori dan praktek. Membangun suatu analisis juga berkaitan dengan pengujian terhadap teori yang berlaku selama ini ${ }^{12}$.

Metode analisa data yang digunakan adalah deskriptif. Menurut Suharsimi deskriptif merupakan penelitian non hipotesis sehingga dalam langkah penelitiannya tidak perlu dirumuskan hipotesis, dengan tujuan untuk mengemukakan data yang digambarkan dengan kata-kata atau kalimat yang dipisah-pisahkan menurut kategori untuk memperoleh kesimpulan. ${ }^{13}$ Implementasi dari analisa data ini adalah mendeskripsikan data yang diperoleh dari masyarakat berdasarkan fenomena yang sedang terjadi secara sistematis dan jelas.

Dari hasil penelitian yang diperoleh melalui penelitian di lapangan dan ditunjang oleh kepustakaan disusun menjadi satu secara sistematis, dengan demikian sumber primer dan sumber skunder saling melengkapi sehingga diperoleh gambaran yang jelas mengenai mekanisme pendayagunaan Dana ZIS yang dilakukan oleh BAZ kabupaten Malang terkait dengan keberadaan UU No. 38 tahun 1999 Pasal 16 tentang Pendayagunaan Zakat dan Keputusan Menteri Agama RI. Nomor 581 Tahun 1999 tentang Pelaksanaan Undang-Undang Nomor 38 Tahun 1999 Pasal 16 dan sistem pendayagunaan zakat.

\section{HASIL DAN PEMBAHASAN}

\section{Hasil}

Sasaran pendayagunaan zakat atau yang lebih kita kenal dengan Mustahiqquzzakah atau Asnaf, ada delapan golongan sebagaimana yang disebut dalam

\footnotetext{
11 Saifullah, Buku Ajar; Metodologi Penelitian Hukum, Bagian I (Malang: STAIN Malang, 2003), 45.

12 Saifullah, Buku Ajar: 45

13 Suharsimi Arikunto, Prosedur Penelitian Suatu Pendekatan (Jakarta: UI Press, 1989), 204
}

al-Qur'an yang berbunyi:

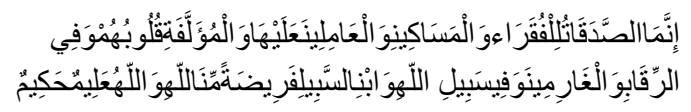

"Sesungguhnya zakat-zakat itu, hanyalah untuk orang-orang fakir, orang-orang miskin, penguruspengurus zakat, para mu'allaf yang dibujuk hatinya, untuk (memerdekakan) budak, orang-orang yang berhutang, untuk jalan Allah dan untuk mereka yang sedang dalam perjalanan, sebagai suatu ketetapan yang diwajibkan Allah, dan Allah Maha mengetahui lagi Maha Bijaksana". ${ }^{14}$

Dilihat dari data yang ada, BAZ Kabupaten Malang nampaknya masih memprioritaskan Fakir-miskin dengan jumlah pendayagunaannya 133. 339,000 dengan posisi $67,17 \%$ yang terdiri dari konsumtif sebesar 177.318,350 dan produktif sebesar 21.200,000, Sabilillah dengan jumlah pendayagunaannya sebesar $64.551,500$ dengan posisi $32,52 \%$, Amil dengan jumlah pendayagunaannya Rp 402.850 dengan posisi $0,20 \%$ dan kemudian Musafir dengan jumlah pendayagunaannya Rp 225.000 dengan posisi 0,11 . Menurut pendapat penulis sasaran pendayagunaan dana ZIS bisa berubah mana yang harus diutamakan untuk mendapatkan dana ZIS yang lebih diprioritaskan dengan merujuk ketentuan-ketentuan yang telah dibuat oleh aturan Agama.

Adapun implementasi pada BAZ Kabupaten Malang tentang sasarannya ini masih cendurung pada sektor fakir-miskin yang berupa pemberdayaan yang sifatnya masih konsumtif, Sebagaimana pada hasil wawancara penulis As'adul Anam mengatakan Untuk pendayagunaan masih dominan yang konsumtif. Mengingat banyaknya orang miskin yang sudah tua, panti asuhan yang memerlukan makanan pokok, TPQ yang masih kekurangan buku-buku tajwid maupun alQur'an, untuk pembangunan Masjid ${ }^{15}$. Dan hal ini diperkuat dengan adanya data yang ada di kantor BAZ Kabupaten Malang pada sektor ini pemberdayaannya $84 \%$ masih bersifat konsumtif sedangkan yang $16 \%$ berupa produktif. ${ }^{16}$

Hal tersebut diperkuat oleh Chamzawi bahwa sesuai dengan kesepakatan pengurus, pada periode 2004-2007 program pendayagunaan lebih mendahulukan konsumtif untuk guru-guru yang kurang mampu dan beragama Islam dan itu dikeluarkan setiap bulan khususnya yang berada di wilayah Malang Selatan. ${ }^{17}$

$\overline{14 \text { QS. at-Taubah (9):60. }}$

15 Wawancara tgl 19 Desember 2008 dengan As'adul Anam Sekretaris BAZ Kabupaten Malang.

16 Data di Ambil Dari Kantor BAZ Kabupaten Malang.

17 Wawancaratgef 9 Wiaret 2008 dengan Chamzawi Unit Pendayagunaan BAZ

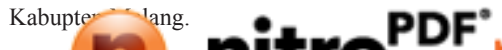


Agar dana zakat yang disalurkan dapat berdaya guna dan berhasil, maka pemanfaatannya harus selektif untuk kebutuhan konsumtif dan produktif. Kebutuhan Konsumtif ini dibagi menjadi dua: Pertama, konsumtif tradisional yang mana pada implementasinya BAZ Kabupaten Malang masih tampak mendayagunakan dana ZIS pada konsumtif tradisional, hal ini sesuai dengan data yang penulis peroleh dari Kantor BAZ Kabupaten Malang. Dari dana yang telah di keluarkan oleh BAZ Kabupaten Malang pada Tahun 2007 sebesar Rp 133.339,000 untuk sektor fakir-miskin yakni untuk dana yang konsumtif sebesar Rp 177.318,000 atau sekitar84\% dan produktif sebesar Rp 21.200,000 atau sekitar 16\%. ${ }^{18}$ Dari data tersebut tampak konsumtif tradisional mendominasi pendayagunaannya, hal ini terlihat dari data yang kami peroleh dari kantor BAZ dengan nilai total RP.120.989,000 atau sekitar 67\%. ${ }^{19}$

Kedua, konsumtif kreatif yang mana pada implementasinya BAZ Kabupaten Malang sudah menerapkan pola pendayagunaan seperti ini akan tetapi kurang optimal. Sebagaimana data yang kami terima bahwa konsumtif kreatif ini pendayagunaannya masih berjalanRp.56.350.000 atau sekitar 33\%. ${ }^{20}$

Sedangkan untuk Kebutuhan produktif dibagi menjadi dua: Pertama, produktif konvensional yang mana pada implementasinya BAZ Kabupaten Malang sudah mampu melaksanakan cara yang produktif konvensional semacam ini akan tetapi masih relatif rendah, dari data yang ada, BAZ Kabupaten Malang pada Tahun 2007 hanya tercatat 1 kali menerapkan untuk usaha produktif konvensional ini bekerjasama untuk pemberdayaan hewan ternak bagi keluarga miskin di Kecamatan Jabung sebanyak 24 kambing dengan biaya $\mathrm{Rp} 19.100,000$ yang sekarang sudah berkembang menjadi 100 kambing. ${ }^{21}$

Kedua, Produktif kreatif yang mana pada implementasinya juga tidak berjalan dengan lancar akan tetapi BAZ Kabupaten pernah memberikan modal bagi mustahiq tepatnya pada bulan januari 2007 pada saudara Lutfi Syarif sebesar Rp 750.000 tetapi tidak berjalan. ${ }^{22}$

Dalam pendayagunaan ada beberapa kegiatan yang dapat dikembangkan. Dalam hal ini penulis merujuk pada Dompet Dhuafa Republika yang memilah ke dalam tiga kegiatan yakni pengembangan Ekonomi,

\footnotetext{
18 Data Di Ambil Dari Kantor BAZ Kabupaten Malang.

19 Data Di Ambil Dari Kantor BAZ Kabupaten Malang.

20 Data Di Ambil Dari Kantor BAZ Kabupaten Malang.

21 Wawancara tgl 19 Desember 2008 dengan As'adul Anam Sekretaris BAZ Kabupaten Malang.

22 Wawancara tgl 19 Desember 2008 dengan As'adul Anam Sekretaris BAZ Kabupaten Malang.
}

pembinaan SDM dan bantuan yang sifatnya sosial semata. Kegiatan ini dapat dikurangi dan ditambah sesuai dengan kemampuan lembaga, tujuan lembaga serta kondisi mustahiq setempat.

Ketiga kegiatan di lembaga zakat kini telah dikembangkan sebagai Divisi: Pertama, Pengembangan Ekonomi, pada realitanya di BAZ Kabupaten Malang,pengembangan ekonomiuntukpemberdayaan dana ZIS di Kabupaten Malang masih tergolong belum bisa berjalan dengan baik karena BAZ Kabupaten Malang ini masih dalam tahap perkembangan untuk menuju perkembangan kegiatan ekonomi tersebut, hal ini dapat kita lihat dari pendayagunaannya yang sudah mulai mengarah pada perkembangan ekonomi semisal untuk modal usaha untuk Lutfi Syarif, dan kerjasama untuk pemberdayaan hewan ternak di Jabung dan sekarang mulai adanya program untuk berinvestasi dengan BMG Sidogiri.

Kedua, pembinaan SDM, dalam membina sumber daya manusia BAZ Kabupaten Malang memberikan beasiswa kepada mustahiq, akan tetapi masih dalam skala kecil (bagi mereka yang mengajukan permohonan). Untuk selanjutnya BAZ Kabupaten Malang masih dalam tahap pemprograman agar untuk tahun selanjutnya diadakan sosialisasi menyeluruh untuk beasiswa yang jangkauannya lebih luas lagi yang diperuntukkan setingkat SD, SMP dan SMA yang ada di wilayah Kabupaten Malang. ${ }^{23}$

Ketiga, kegiatan Sosial, layanan sosial yang dimaksud yaitu layanan yang diberikan kepada kalangan mustahiq dalam memenuhi kebutuhan mereka. Kebutuhan mustahiq sangat beragam tergantung dengan kondisi yang tengah di hadapi. Seperti untuk kebutuhan sehari-hari, kebutuhan pengobatan, bayar SPP, biaya ambil ijazah, bahkan juga permohonan modal kerja untuk berjualan. Dan yang jelas semua permohonan rata-rata memang berasal dari pihak-pihak yang terpaksa harus meminta kepada lembaga zakat, karena tak punya akses mendapat bantuan modal dari lembaga lain.

Menurut As'adul Anam dalam kegiatan sosial ini, BAZ Kabupaten sudah mulai melakukan kegiatan sosial di antaranya bantuan bencana alam untuk korban gempa di Yogyakarta, kemudian bantuan tanah longsor di Kasembon dan juga pembayaran SPP untuk siswa yang berprestasi kepada sekolah-sekolah Islam. ${ }^{24}$

\footnotetext{
23 Wawancara tgl 19 Desember 2008 dengan As'adul Anam Sekretaris BAZ Kabupaten Malang

24 Wawancara tgif 19 Dithember 2008 dengan As'adul Anam Sekretaris BAZ

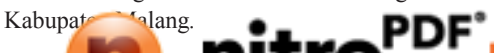




\section{Pembahasan}

Upaya optimalisasi oleh pemerintah Kabupaten Malang untuk menjadikan pendayagunaan dana ZIS Kabupaten Malang sesuai dengan Undang Undang Zakat Pasal 16 membutuhkan kerja keras, kerjasama yang baik antar pengelola dan mustahiq serta semangat yang tinggi, akan tetapi dalam implementasinya masih belum menampakkan keberhasilan sehingga masih terkesan pendayagunaannya masih belum bisa menyeluruh dan merata ke seluruh wilayah Malang.

Sesuai dengan saran Chamzawi untuk mencapai hasil yang maksimal harus dilakukan dengan kerja sama yang baik antara pengurus BAZ Kabupaten Malang sehingga sesuai dengan yang diharapkan oleh UU No 38 pasal 16, begitu pula kerja sama yang baik antara pengurus BAZ Kabupaten Malang dengan mustahiq sehingga program-program bisa berjalan dengan ideal. ${ }^{25}$

Pendayagunaan dana ZIS merupakan sektor penting, semestinya membutuhkan upaya dan penanganan yang serius dan tekad yang bulat untuk menjalankan kreatifitas pendayagunaan. Realitanya belum ada upaya untuk menerapkan pasal 16 secara optimal. Bukankah potensi pendayagunaan dana ZIS ini akan bermanfaat sekali untuk mustahiq sehingga mustahiq yang semestinya mendapatkan dana ZIS bisa menjadi muzaki.

Setelah penulis meneliti hasil pendayagunaan terkait BAZ Kabupaten Malang, sejauh ini BAZ Kabupaten Malang telah mendayagunakan dana ZIS sesuai ketentuan Agama dan UU No. 38 Pasal 16 Ayat 1 bahwa pendayagunaannya harus digunakan untuk kebutuhan mustahiq sesuai dengan ketentuan agama, yang mana pada Tahun 2007 BAZ Kabupaten Malang mengimplementasikannya dengan jumlah 198.518,350 yang terdiri dari Fakir-miskin dengan jumlah pendayagunaannya $133.339,000$ dengan posisi $67,17 \%$ yang terdiri dari konsumtif sebesar 177.318,350 dan produktif sebesar 21.200,000, Sabilillah dengan jumlah pendayagunaannya sebesar $64.551,500$ dengan posisi 32,52\%, Amil dengan jumlah pendayagunaannya $\mathrm{Rp} 402.850$ dengan posisi $0,20 \%$ dan kemudian Musafir dengan jumlah pendayagunaannya $\mathrm{Rp} 225.000$ dengan posisi 0,11 .

Dari data diatas, implementasi pendayagunaan dana ZIS pada tahun 2007 masih tampak pada konsumtif tradisional ini, hal ini sesuai dengan data yang penulis peroleh dari Kantor BAZ Kabupaten Malang. Dari dana yang telah di keluarkan oleh BAZ

\footnotetext{
25 Wawancara tgl 19 Maret 2008 dengan Chamzawi Unit Pendayagunaan BAZ Kabupaten Malang.
}

Kabupaten Malang pada Tahun 2007 sebesar Rp. 133.339,000 untuk sektor fakir-miskin dana yang konsumtif sebesar 177.318,000 atau sekitar $84 \%$ dan produktif sebesar Rp 21.200,000 atau sekitar 16\%. ${ }^{26}$

Prioritas pendayagunaan di BAZ Kabupaten Malang ini dibentukkan dalam program bentuk konsumtif dan produktif. Yang mana BAZ Kabupaten Malang pada implementasinya masih dominan mendayagunakan dana ZIS pada konsumtif dari pada produktif. Untuk mensejahterakan masyarakat Kabupaten Malang ini tidak bisa dengan hanya yang konsumtif saja. Bahkan lebih perlu produktif dari pada konsumtif, Hal ini terbalik dengan apa yang terjadi di BAZ Kabupaten Malang. Hal ini disebabkan kurang adanya kerja sama yang baik antara pengelola dan unit pendayagunaan, sehingga pengelola BAZ Kabupaten Malang terkesan tidak kompak dan bekerja sendiri. Kemudian kreatifitas dari pengelola yang kurang optimal dan tidak mau resiko, sehingga pendayagunaan zakat BAZ Kabupaten Malang ini masih $67 \%$ konsumtif.

Padahal sesuai dengan UU No. 38 Poin (2) Pendayagunaan hasil pengumpulan zakat berdasarkan skala prioritas kebutuhan mustahiq dan dapat dimanfaatkan untuk usaha yang produktif. Dari ayat ini sebenarnya BAZ Kabupaten Malang diberi kebebasan untuk mengoptimalkan dana BAZ untuk kebutuhan produktif. Karena dengan pendayagunaan produktif inilah yang nantinya akan menjadikan mustahiq menjadi muzaki.

Sesuai dengan tujuan BAZ Kabupaten Malang (meningkatkan hasil guna dan daya guna zakat) BAZ Kabupaten Malangharusnyamampumendayagunakan dana ZIZ untuk keperluan konsumtif dan produktif dengan seimbang, dengan begitu nanti hasilnya akan lebih nyata bagi mustahiq baik itu mustahiq yang tidak mampu bekerja lagi, orang-orang tua maupun janda yang mana pendayagunaannya bersifat permanen ataupun mustahiq yang kreatif dan mampu bekerja.

Menurut penulis agar BAZ Kabupaten Malang ini bisa berhasil seharusnya harus lebih mendahulukan pendayagunaan yang produktif dari pada konsumtif, sehingga mustahiq nantinya akan aktif dan mempunyai lapangan pekerjaan, pendayagunaannya bisa bergilir, merata dan berguna seterusnya tidak menunggu lagi bantuan dari dana ZIS melainkan mustahiq produktif tersebut menjadi muzaki.

Pendayagunaan yang produktif akan menjadikan mustahiq tersebut terangkat ekonominya dan tidak menunggu lagi bantuan dari dana ZIS melainkan mus26 Data Di Dari Kant BAZ Kabu D D Dang. 
tahiq produktif tersebut menjadi muzaki, sehingga BAZ Kabupaten Malang mendapatkan pengumpulan yang lebih banyak lagi, dengan begitu BAZ Kabupaten Malang mendapatkan pengumpulan terus-menerus dan bisa leluasa mendayagunakan untuk mustahiq yang lain.

Minimnya dana produktif pada tahun 2007 ini berpengaruh pada beban hidup mustahiq untuk selanjutnya, oleh karena itu agar tidak menjadi beban hidup, Penulis berharap pada BAZ Kabupaten Malang untuk tahun selanjutnya lebih memfokuskan dana produktif minimal antara yang konsumtif dan yang produktif sama, karena tindakan tersebut akan meminimalisir kekurangan mustahiq untuk kehidupan sehari-hari, lebih-lebih dana produktif tersebut dapat berkembang sehingga mustahiq tersebut menjadi muzaki.

Agar mustahiq tersebut bisa berkembang dan maju, sehingga tidak membutuhkan dana ZIS lagi dibutuhkan upaya-upaya kegiatan pendayagunaan dana ZIS yang itu nantinya dapat membantu kesulitan mustahiq dalam mengembangkan usahanya, seperti pengembangan ekonomi, pembinaan SDM bahkan kegiatan sosial.

Akan tetapi kegiatan pengembangan ekonomi BAZ Kabupaten Malang sampai saat ini belum bisa dirasakan oleh masyarakat luas, dari data penulis pada tahun 2007 BAZ Kabupaten Malang hanya mengimplementasikan modal usaha untuk Lutfi Syarif sebesar Rp 750.000 dan kerjasama untuk pemberdayaan hewan ternak di Jabung. Hal ini disebabkan oleh lambannya kinerja BAZ Kabupaten Malang yang kurang maksimal seperti kecenderungan BAZ Kabupaten Malang yang menunggu pemberitahuan dulu dari pada mengsosialisasikan, kurang solidnya personel sehingga tampak lamban kinerjanya, jumlah personel yang kurang memadai sehingga yang bekerja hanya Seretaris, Bendahara dan satu pembantu umum dan lain-lain.

Dalam membina SDM BAZ Kabupaten Malang memberikan beasiswa kepada mustahiq tetapi masih dalam skala kecil (bagi mereka yang mengajukan permohonan). Untuk selanjutnya BAZ Kabupaten Malang masih dalam tahap pemprograman agar untuk tahun selanjutnya diadakan sosialisasi menyeluruh untuk beasiswa yang jangkauannya lebih luas lagi yang diperuntukkan setingkat SD, SMP dan SMA yang ada di wilayah Kota malang. ${ }^{27}$

Menurut As'adul Anam dalam kegiatan sosial ini BAZ Kabupaten sudah mulai melakukan kegiatan so-

27 Wawancara tgl 19 Desember 2008 dengan As'adul Anam Sekretaris BAZ Kabupaten Malang sial di antaranya bantuan bencana alam untuk korban gempa di Yogyakarta, kemudian bantuan tanah longsor di Kasembon dan juga pembayaran SPP untuk siswa yang berprestasi kepada sekolah-sekolah Islam. ${ }^{28}$

Sejauh ini BAZ Kabupaten Malang belum bisa melaksanakan dengan maksimal, karena BAZ Kabupaten Malang dalam pengembangan ekonomi ini hanya mampu memberikan modal usaha untuk ternak kambing saja di Kecamatan Jabung dan bantuan modal usaha untuk Lutfi Syareif sebanyak Rp 750.000 , kemudian yang lain pembinaan SDM yang mana BAZ Kabupaten Malang memberikan beasiswa-beasiswa pada siswa yang berprestasi dan tidak mampu walaupun minim dan kegiatan social untuk korban gempa di Yogyakarta dan tanah longsor di kasembon.

BAZ Kabupaten Malang, dengan mengacu kepada UU No. 38 tahun 1999 Pasal 16 tersebut sudah berupaya untuk mendayagunakan zakat secara profesional, akan tetapi pada pertengahan terjadi komunikasi yang lamban dan terkesan bekerja sendiri sehingga tidak semua apa yang di rencanakan akan berjalan dengan maksimal ${ }^{29}$, mengingat BAZ Kabupaten Malang masih membutuhkan pengelola yang amanah dan profesional, perjuangan yang sangat panjang dan terus berbenah untuk mencari sebuah solusi yang tepat agar tercapai tujuan-tujuan tersebut dan hal itu membutuhkan proses yang lama.

Implementasi pendayagunaan zakat, terkait dengan UU Nomor 38 tahun 1999 Pasal 16 harus benarbenar optimal dalam memaksimalkan potensi pemberdayaan Dana ZIS di Kabupaten Malang. Sehingga dengan pemberdayaan yang tepat kemiskinan di Negara Indonesia khususnya Kabupaten Malang dapat di minimalkan.

\section{KESIMPULAN DAN SARAN}

\section{Kesimpulan}

Berdasarkan hasil penelitian tentang Implementasi UU Nomor 38 tahun 1999 pasal 16 tentang pendayagunaan Zakat di BAZ Kabupaten Malang, maka peneliti dapat mengambil kesimpulan, bahwa: (1) BAZ Kabupaten Malang tampaknya masih dominan mendahulukan kebutuhan yang konsumtif dari pada pada produktif, hal tersebut disebabkan kurang adanya kerja sama yang baik antara pengelola

\footnotetext{
28 Wawancara tgl 19 Desember 2008 dengan As'adul Anam Sekretaris BAZ Kabupaten Malang

29 Wawancaratge 99 Mith 2008 dengan Chamzawi Unit Pendayagunaan BAZ (nitis nitro ${ }^{\mathrm{PDF}}$
} 
dan unit pendayagunaan, antara pengelola dan mustahiq, kemudian kurangnya pengelola dalam mengarahkan sasarannya. (2) Sesuai dengan UU No. 38 tahun 1999 tentang pendayagunaan zakat poin pertama BAZ Kabupaten Malang sejauh ini mampu mendayagunakan dana ZIS untuk mustahiq, yang mana pendayagunaannya pada tahun 2007 didayagunakan untuk fakir-miskin yang berupa konsumtif dan produktif.

\section{Saran}

Setelah penelitian ini terselesaikan, peneliti menyarankan bahwa: Pertama, hendaknya BAZ Ka-

\section{DAFTAR RUJUKAN}

Abdusshomad, Muhyiddin. 2004. Fiqih Tradisionalis. Surabaya: Khalista.

Abu, Muhammad Zahrah. 1995. Zakat Dalam Perspektif Sosial. Jakarta: Pustaka Firdaus.

Adi, Rianto. 2004. Metodologi Penelitian Sosial dan Hukum. Jakarta: Granit.

Arfawie, Nukthoh Kurde. 2005. Memungut Zakat \& Infaq Profesi Oleh Pemerintah daerah (bagi pegawai neeri dan pegawai perusahaan daerah). Yogyakarta: Pustaka Pelajar.

Arikunto, Suharsimih. 1989. Prosedur Penelitian Suatu Pendekatan. Jakarta: UI. Press.

Bagir, Muhammad al-Habsyi. 1999. Fiqh Praktis. Bandung: Mizan.

Departemen Agama RI. 1989. Al-Qur'an dan Terjemahannya. Surabaya: Mahkota.

Departemen Agama RI. 2004. Pola Pembinaan Badan Amil Zakat. Jakarta: Direktorat Pengembangan Zakat dan Wakaf.

Departemen Agama RI. 2005. Manajemen Pengelolaan Zakat. Jakarta: Direktorat Pengembangan Zakat dan Wakaf.

Ghozali, Syukri dkk. 1989. Pedoman Zakat 9 seri. Jakarta: Proyek Pembinaan Zakat dan Wakaf.

Hadi, Sjechul Permono. 2001. UU Nomor 38 Tahun 1999 dan pemberdayaan pengelolaan Zakat. Makalah disajikan pada Rapat Kerja Badan Amil Zakat Kabupaten Malang: Aula Pemerintah Kabupaten Malang.

1993. Sumber-Sumber Penggalian Zakat. Jakarta: Pustaka Firdaus.

Hadikusuma, Hilman. 1995. Metode Pembuatan Kertas kerja atau Skripsi Ilmu Hukum. Bandung: Mandar Maju.

Hafidhuddin, Didin. 1998. Panduan Praktis Tentang Zakat Infaq Shadaqah. Jakarta: Gema Insani. bupaten Malang mampu mendayagunakan dana ZIS secara tepat guna, efektif, dengan distribusi yang serbaguna, dan produktif, sesuai dengan pesan dan kesan syari'ah, serta tujuan sosial untuk mensejahterakan mustahiq. Kedua, hendaknya BAZ Kabupaten Malang ke depan lebih menyeimbangkan kebutuhan konsumtif dan produktif sehingga di samping BAZ Kabupaten Malang mengeluarkan dana ZIS tersebut juga mendapatkan pemasukan dari hasil yang produktif, yang mana pada nantinya mustahiq tersebut tidak membutuhkan dana tersebut lebih-lebih menjadi muzaki.

Ibrahim, Yasin al-Syaikh. 2004. Zakat Menyempurnakan Puasa Membersihkan Harta. Bandung: Komp. Cijambe Indah.

Ja'far, Muhammadiyah. 1985. Zakat, Puasa dan Haji. Surabaya: Kalam Mulia.

Jawad, Muhammad Mughniyah. 1999. Fiqh Lima Mazdhab, terj. Masykur A.B dkk, Jakarta: Lentera Basritami.

Muhammad, Imam, Ibnu Ismail. 1926. Subulus Salam Juz II. Surabaya: Alhidayah.

Muhammad. 2002. Zakat Profesi Wacana Pemikiran dalam Fiqh Kontemporer. Jakarta: Salemba Diniyati.

Qadir, Abdurrahman. 1998. Zakat dalam Dimensi Mahdhah dan Sosial. Jakarta: PT. Raja Grafindo Persada.

Qardawi, Yusuf. 1996. Hukum zakat. Bogor: Litera Antar Nusa dan Mizan.

Shomad, abdul. 2007. Pernak-pernik zakat di jawa Timur. Surabaya: Depag.

Soekanto, Soerjono. 1986. Pengantar Penelitian Hukum. Jakarta: UI Press.

Sudewo, Eri. 2004. Manajemen Zakat. Ciputat: Institut Manajemen Zakat.

Sunggono, Bambang. 1997. Metodologi Penelitian Hukum. Jakarta: PT. Raja Grafindo Persada.

Tim Dosen Fakultas Syariah. 2005. Buku Pedoman Penulisan Karya Ilmiah. Malang: Fakultas Syariah UIN.

Tim Proyek Pembinaan Zakat dan Wakaf. 1989. Pedoman Zakat 9 seri. Jakarta: Proyek Pembinaan Zakat dan Wakaf.

Zuhdi, Masjfuk. 1986. Pengelolaan Zakat Ditinjau dari Aspek Hukum Islam, Sosial \& Ekonomi. Bontang: BDI-LNG. 